\title{
Flavobacterium phragmitis sp. nov., an endophyte of reed (Phragmites australis)
}

Correspondence

Yan Hong Li

liyh@mail.cnu.edu.cn

\author{
Min Liu, ${ }^{1 \dagger}$ Yan Hong Li, ${ }^{1 \dagger}$ Yang Liu, ${ }^{1}$ Jing Nan Zhu, ${ }^{1}$ Oun Fang Liu, ${ }^{1}$ \\ Yin Liu, ${ }^{1}$ Jin Gang Gu, ${ }^{2}$ Xiao Xia Zhang ${ }^{2}$ and Chun Li Li ${ }^{3}$ \\ ${ }^{1}$ College of Life Science, Capital Normal University, Beijing 100048, PR China \\ ${ }^{2}$ Institute of Agricultural Resources and Regional Planning, Chinese Academy of Agricultural \\ Sciences, Beijing 100081, PR China \\ ${ }^{3} \mathrm{New}$ Technique Centre, Institute of Microbiology, Chinese Academy of Sciences, Beijing 100101 , \\ PR China
}

\begin{abstract}
A Gram-staining-negative bacterium, designated strain $\mathrm{BLN}^{\top}$, was isolated from within the roots of reeds (Phragmites australis) in Beijing Cuihu Wetland (China) and characterized using a polyphasic taxonomic approach. The cells were yellow-pigmented, rod-shaped, strictly aerobic and devoid of flagella, but showed gliding motility. Strain $B L N 2^{\top}$ produced yellow, translucent, circular and convex colonies, with optimal growth at $30{ }^{\circ} \mathrm{C}$ and $\mathrm{pH}$ 7.0. The major respiratory quinone was menaquinone $6(\mathrm{MK}-6)$ and the predominant fatty acids were iso- $\mathrm{C}_{15: 0}$, summed feature 3 (comprising $\mathrm{C}_{16: 1} \omega 7 c$ and/or $\mathrm{C}_{16: 1} \omega 6 c$ ), $\mathrm{C}_{16: 0} 3-\mathrm{OH}, \mathrm{C}_{16: 0}$, iso- $\mathrm{C}_{17: 0} 3-\mathrm{OH}$ and iso- $\mathrm{C}_{15: 0} 3-\mathrm{OH}$. The $\mathrm{G}+\mathrm{C}$ content of the genomic DNA was $34.8 \mathrm{~mol} \%$. The $16 \mathrm{~S}$ rRNA gene sequence analysis showed that strain $\mathrm{BLN}^{\top}$ belonged to the genus Flavobacterium and was most closely related to Flavobacterium anhuiense CGMCC $1.6859^{\top}$ (97.0\% sequence similarity). The DNA-DNA relatedness between strain BLN2 ${ }^{\top}$ and $F$. anhuiense CGMCC $1.6859^{\top}$ was $25.7 \%$. Based on the phenotypic data and phylogenetic inference presented, it is concluded that strain $B L N 2^{\top}$ represents a novel species within the genus Flavobacterium, for which the name Flavobacterium phragmitis sp. nov. is proposed. The type strain is BLN2 ${ }^{\top}$ (=DSM $23314^{\top}=$ CGMCC $1.10370^{\top}$ ).
\end{abstract}

Since the description of the genus Flavobacterium was emended by Bernardet et al. (1996) to group Gramstaining-negative, aerobic, predominantly gliding, yellowpigmented bacteria with DNA $\mathrm{G}+\mathrm{C}$ contents in the range of $32-37 \mathrm{~mol} \%$, many additional species have been described from diverse environments, such as a glacier (Xin et al., 2009), a eutrophic lake (Qu et al., 2009), a hard water rivulet (Ali et al., 2009), a freshwater lake (Kim et al., 2009), marine algae (Miyashita et al., 2010), stream sediment (Lee et al., 2010) and sludge (Liu et al., 2010), but no endophytic members of the genus have been described so far. In this paper, the taxonomic characterization of a novel bacterial strain $\mathrm{BLN} 2^{\mathrm{T}}$ is reported. The strain was isolated from within the roots of reeds (Phragmites australis). Biochemical and chemotaxonomic data, 16S rRNA gene sequencing and DNA-DNA relatedness analysis showed that this bacterial isolate constitutes a novel species of the genus Flavobacterium.

†These authors contributed equally to this work.

Abbreviations: MP, maximum-parsimony; $\mathrm{NJ}$, neighbour-joining.

The GenBank/EMBL/DDBJ accession number for the 16S rRNA gene sequence of strain BLN2 ${ }^{\top}$ is GU564236.
Reed roots were collected $15 \mathrm{~cm}$ below the water surface from the constructed Beijing Cuihu Wetland, China. Surface disinfection of the roots was conducted as previously described (Li et al., 2010). Roots were crushed in a ceramic mortar, diluted with sterile double distilled water and plated on Luria-Bertani (LB) agar using the standard dilution plating technique. Strain BLN2 ${ }^{\mathrm{T}}$ was isolated after incubation for $16 \mathrm{~h}$ at $30{ }^{\circ} \mathrm{C}$. The new isolate was maintained on LB agar slants at $4{ }^{\circ} \mathrm{C}$ and as a glycerol suspension $(25 \% \mathrm{v} / \mathrm{v})$ in $\mathrm{LB}$ broth at $-70{ }^{\circ} \mathrm{C}$.

Preparation of genomic DNA was performed according to the method of Marmur (1961). The 16S rRNA gene sequence of strain BLN2 ${ }^{\mathrm{T}}$ was determined by PCR amplification using the primers 27f and 1492r (Lane, 1991). The amplification product (1475 bp) was purified and cloned into a pMD18-T vector (Takara). Sequencing was performed by using an ABI Big Dye Primer Cycle Sequencing Ready Reaction kit and an Applied Biosystems 3730 DNA sequencer. The 16S rRNA gene sequence of strain $\mathrm{BLN} 2^{\mathrm{T}}$ was first analysed using the EzTaxon server 2.1 (Chun et al., 2007) to determine the closest type strains. The sequence was then aligned with those of related species and phylogenetic trees were constructed using the neighbour-joining (NJ) (Saitou \& 
Nei, 1987) and maximum-parsimony (MP) methods in the MEGA 4.0 software (Tamura et al., 2007). Bootstrap analysis (1000 replications) was used to evaluate the topology of the trees. Comparative 16S rRNA gene sequence analysis showed that strain BLN2 $2^{\mathrm{T}}$ was most closely related to Flavobacterium anhuiense CGMCC $1.6859^{\mathrm{T}}$ (97.0\% sequence similarity) (Liu et al., 2008), and shared 96.8, 96.0 and $95.7 \%$ 16S rRNA gene sequence similarity with Flavobacterium denitrificans DSM $15936^{T}$ (Horn et al., 2005), Flavobacterium defluvii DSM $17963^{\mathrm{T}}$ (Park et al., 2007) and Flavobacterium johnsoniae JCM $8514^{\mathrm{T}}$ (Bernardet et al., 1996), respectively. The NJ phylogenetic tree is presented in Fig. 1. The MP tree showed essentially the same topology (data not shown). Both trees showed that strain $B L N 2^{\mathrm{T}}$ is a member of the genus Flavobacterium, joining the cluster comprising the type strains with higher sequence similarity with a bootstrap value of $94 \%$. Since F. anhuiense CGMCC $1.6859^{\mathrm{T}}$, F. denitrificans DSM $15936^{\mathrm{T}}, F$. defluvii DSM $17963^{\mathrm{T}}$ and F. johnsoniae JCM $8514^{\mathrm{T}}$ were the closest relatives and clustered together with strain $\mathrm{BLN} 22^{\mathrm{T}}$, they were used as reference strains for further taxonomic studies.

Cell morphology was examined by light and scanning electron microscopy (scanning fibre-optic microscope; FEI QUANTA) and colony morphology was observed on LB agar. Growth was assessed at $4,15,25,28,30,35,37$ and $42{ }^{\circ} \mathrm{C}$ on $\mathrm{LB}$ agar. Tolerance to $\mathrm{NaCl}$ and $\mathrm{pH}$ was tested for 7 days at $30{ }^{\circ} \mathrm{C}$ in LB broth containing $0,1,2,3,5$ and $7 \%$ $\mathrm{NaCl}(\mathrm{w} / \mathrm{v}$ ) or adjusted to $\mathrm{pH} 4.0-11.0$ (at $0.5 \mathrm{pH}$ unit intervals), respectively, according to Zhou et al. (2007). Growth was also evaluated on trypticase-soy agar (TSA) and nutrient agar (NA).

Gram staining was performed using a standard procedure (Hucker \& Conn, 1923). Endospore and flagellum staining were conducted according to the methods described by Smibert \& Krieg (1994). Gliding motility, the production of flexirubin-type pigments and the adsorption of Congo red by colonies were tested as previously described by Bernardet et al. (2002). Production of catalase, oxidase, indole and $\mathrm{H}_{2} \mathrm{~S}$, degradation of agar, CM-cellulose, gelatin, starch and L-tyrosine and anaerobic growth were assessed according to the methods of Lewin \& Lounsbery (1969). Urease activity was determined as described by Cowan \& Steel (1965). Reduction of nitrate and hydrolysis of Tween 80, Tween 20 and aesculin were determined according to the methods of Lányí (1987). Methyl red and VogesProskauer reactions, utilization of sodium citrate and arginine dihydrolase activity were assessed as described by Dong \& Cai (2001). Carbon-source utilization was assessed by using the GN2 MicroPlate system (Biolog) and the test was read after incubation at $30{ }^{\circ} \mathrm{C}$ for $24 \mathrm{~h}$. Antibiotic sensitivity tests were performed after incubation at $30{ }^{\circ} \mathrm{C}$ for $72 \mathrm{~h}$ on LB agar containing the following antibiotics $\left(\mu \mathrm{g} \mathrm{ml}^{-1}\right)$ : ampicillin $(5,50,100)$, chloramphenicol $(5,50$, $100)$, gentamicin $(5,50,100)$, kanamycin $(5,50,100)$, carbenicillin $(5,50,100)$, rifampicin $(5,50,100)$, streptomycin $(5,50,100)$ and hygromycin $(5,50,100)$.

All conventional phenotypic tests cited were performed in parallel on the new isolate and on the four reference strains. The phenotypic characteristics of strain $\mathrm{BLN} 2^{\mathrm{T}}$ are given in the species description and Table 1 shows the features that differentiate the new strain from other closely related species of the genus Flavobacterium.

To determine the whole-cell fatty acid composition, strain $\mathrm{BLN} 2^{\mathrm{T}}$ and the four reference strains were grown on TSA at $30{ }^{\circ} \mathrm{C}$ for $24 \mathrm{~h}$. Extraction and analysis of the cellular fatty acids were performed according to the standard protocol of the Sherlock Microbial Identification system (MIDI; Sasser, 1990) version 6.0 and peaks were identified using the peak naming table TSBA6 6.00. The complete fatty acid profiles of strain $B L N 2^{\mathrm{T}}$ and its phylogenetic relatives are given in Table 2 . The major fatty acids of strain BLN2 ${ }^{\mathrm{T}}$ were: iso- $\mathrm{C}_{15: 0}(20.7 \%)$, summed feature 3 (comprising $\mathrm{C}_{16: 1} \omega 7 c$ and/or $\mathrm{C}_{16: 1} \omega 6 c, 19.6 \%$ ), $\mathrm{C}_{16: 0}$ $3-\mathrm{OH}(9.1 \%), \mathrm{C}_{16: 0}(8.9 \%)$, iso- $\mathrm{C}_{17: 0} 3-\mathrm{OH}(8.7 \%)$ and iso- $\mathrm{C}_{15: 0} 3-\mathrm{OH}(7.0 \%)$. This fatty acid profile was very similar to those of the four reference strains, although there

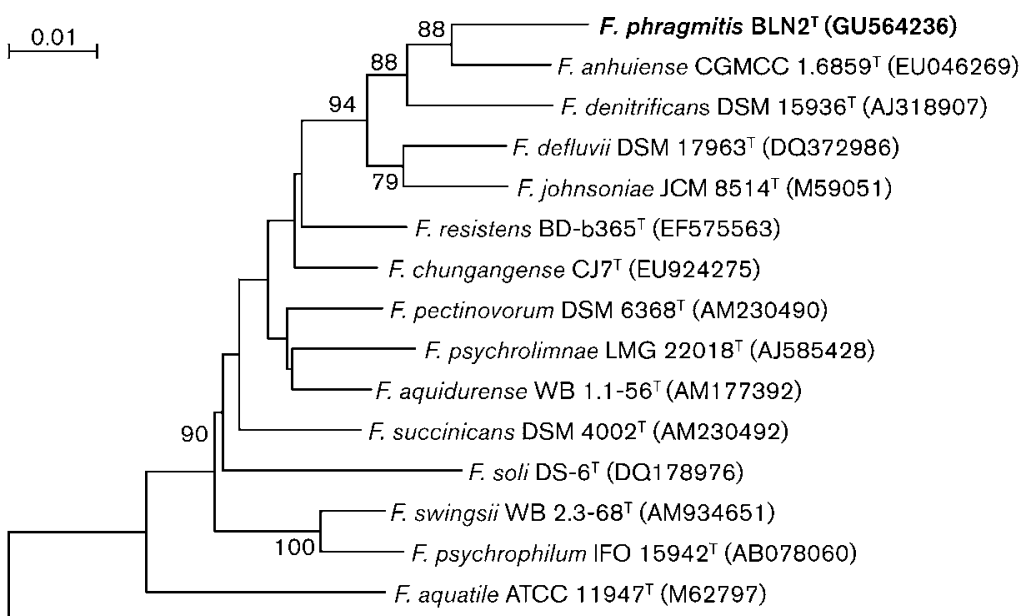

Myroides odoratus ATCC $4651^{\top}$ (M58777)
Fig. 1. Neighbour-joining phylogenetic tree based on 16S rRNA gene sequences showing the relationships of strain $B L N 2^{\top}$ and representative members of the genus Flavobacterium. GenBank accession numbers are given in parentheses. Numbers at branching points are bootstrap values $>70 \%$. Myroides odoratus ATCC $4651^{\top}$ was used as an outgroup. Bar, 0.01 substitution per nucleotide position. 
Table 1. Differential characteristics of strain $\mathrm{BLN}^{\top}$ and related species of the genus Flavobacterium

Strains: 1 , BLN2 ${ }^{\mathrm{T}} ; 2$, F. anhuiense CGMCC $1.6859^{\mathrm{T}} ; 3$, F. defluvii DSM $17963^{\mathrm{T}} ; 4$, F. denitrificans DSM $15936^{\mathrm{T}} ; 5$, F. johnsoniae JCM $8514^{\mathrm{T}}$. + , Positive result; -, negative result; $\mathrm{w}$, weak or delayed reaction; I, intermediate resistance. All data from this study, except the DNA G $+\mathrm{C}$ content of the reference strains. Data from Liu et al. (2008), Park et al. (2007), Horn et al. (2005), and Bernardet et al. (1996) that differed from our own data are shown in parentheses.

\begin{tabular}{|c|c|c|c|c|c|}
\hline Characteristic & 1 & 2 & 3 & 4 & 5 \\
\hline Tolerance to $2 \% \mathrm{NaCl}$ & + & + & - & + & + \\
\hline \multicolumn{6}{|l|}{ Degradation of: } \\
\hline Tween 20 & + & - & + & - & + \\
\hline Tween 80 & + & - & - & - & + \\
\hline CM-cellulose & $\mathrm{W}$ & - & + & + & + \\
\hline L-Tyrosine & - & + & - & - & + \\
\hline \multicolumn{6}{|l|}{ Resistant to: } \\
\hline Streptomycin $\left(100 \mu \mathrm{g} \mathrm{ml}^{-1}\right)$ & + & $+(-)$ & I $(-)$ & - & + \\
\hline Ampicillin $\left(100 \mu \mathrm{g} \mathrm{ml}^{-1}\right)$ & + & $+(-)$ & I & - & + \\
\hline DNA G $+C$ content $(\mathrm{mol} \%)$ & 34.8 & 31.4 & 33.5 & 34.6 & 35.2 \\
\hline
\end{tabular}

were significant differences in the proportions of some fatty acids (e.g. $\mathrm{C}_{16: 0} 3-\mathrm{OH}$, iso- $\mathrm{C}_{17: 0} 3-\mathrm{OH}$ and summed feature 3 ).

Table 2. Fatty acid composition (\%) of strain $B L N 2^{\top}$ and related species of the genus Flavobacterium

Strains: $1, \mathrm{BLN} 2^{\mathrm{T}} ; 2$, F. anhuiense CGMCC $1.6859^{\mathrm{T}} ; 3$, F. defluvii DSM $17963^{\mathrm{T}} ; 4$, F. denitrificans DSM $15936^{\mathrm{T}} ; 5$, F. johnsoniae JCM $8514^{\mathrm{T}}$. tr, Traces $(<1 \%$ of the total). All data from this study. Fatty acids amounting to $<1 \%$ of the total fatty acids in all strains are not shown.

\begin{tabular}{|c|c|c|c|c|c|}
\hline Fatty acid & 1 & 2 & 3 & 4 & 5 \\
\hline $\mathrm{C}_{14: 0}$ & 1.3 & 1.5 & $\operatorname{tr}$ & $\operatorname{tr}$ & 1.1 \\
\hline $\mathrm{C}_{16: 0}$ & 8.9 & 11.6 & 4.7 & 4.6 & 11.3 \\
\hline iso- $\mathrm{C}_{15: 0}$ & 20.7 & 20.2 & 19.9 & 20.4 & 21.0 \\
\hline iso- $\mathrm{C}_{16: 0}$ & $\operatorname{tr}$ & $\operatorname{tr}$ & 1.9 & 3.3 & 1.3 \\
\hline anteiso- $\mathrm{C}_{15: 0}$ & 2.3 & 2.0 & 3.3 & 4.1 & 2.2 \\
\hline $\mathrm{C}_{15: 1} \omega 6 c$ & 2.4 & 2.6 & 1.9 & 4.2 & 2.1 \\
\hline $\mathrm{C}_{17: 1} \omega 6 c$ & 2.5 & 2.0 & 4.2 & 4.2 & 2.5 \\
\hline $\mathrm{C}_{17: 1} \omega 8 c$ & 1.4 & 1.4 & 3.2 & 3.6 & 1.7 \\
\hline iso- $\mathrm{C}_{15: 1} \mathrm{G}$ & 2.0 & 2.7 & 1.6 & 3.1 & 1.5 \\
\hline iso- $\mathrm{C}_{17: 1} \omega 9 c$ & 1.5 & 1.5 & 9.0 & 5.9 & 2.6 \\
\hline $\mathrm{C}_{15: 0} 3-\mathrm{OH}$ & 1.8 & 1.9 & 2.2 & 1.9 & 1.4 \\
\hline $\mathrm{C}_{16: 0} 3-\mathrm{OH}$ & 9.1 & 9.3 & $\operatorname{tr}$ & 1.3 & 6.2 \\
\hline $\mathrm{C}_{17: 0} 3-\mathrm{OH}$ & 1.0 & 1.0 & 1.1 & 1.3 & $\operatorname{tr}$ \\
\hline iso- $\mathrm{C}_{15: 0} 3-\mathrm{OH}$ & 7.0 & 5.5 & 10.2 & 7.2 & 5.5 \\
\hline iso- $\mathrm{C}_{16: 0} 3-\mathrm{OH}$ & 1.6 & 1.3 & 1.4 & 2.0 & 1.5 \\
\hline iso- $\mathrm{C}_{17: 0} 3-\mathrm{OH}$ & 8.7 & 5.8 & 15.6 & 12.5 & 8.9 \\
\hline Summed feature 3 & 19.6 & 21.5 & 7.6 & 7.4 & 20.1 \\
\hline
\end{tabular}

${ }^{*}$ Summed features represent groups of two or three fatty acids that could not be separated by GLC using the MIDI system. Summed feature 3 contained $\mathrm{C}_{16: 1} \omega 7 c$ and/or $\mathrm{C}_{16: 1} \omega 6 c$.
Isoprenoid quinone analysis was performed according to Komagata \& Suzuki (1987), using cells harvested from a LB broth culture incubated at $30{ }^{\circ} \mathrm{C}$ for 2 days. The predominant isoprenoid quinone was menaquinone 6 (MK-6), in line with all other recognized members of the family Flavobacteriaceae.

The $\mathrm{G}+\mathrm{C}$ content of the genomic DNA was determined using the thermal denaturation method (Marmur \& Doty, 1962) with Escherichia coli K-12 as a control. The G+C content of the DNA of strain $\mathrm{BLN} 2^{\mathrm{T}}$ was $34.8 \mathrm{~mol} \%$, a value within the range $(32-37 \mathrm{~mol} \%)$ originally reported for members of the genus Flavobacterium by Bernardet et al. (1996). Higher values have been reported subsequently for newly described species (e.g. $41 \mathrm{~mol} \%$ for Flavobacterium croceum and Flavobacterium saliperosum; Park et al., 2006; Wang et al., 2006).

DNA-DNA hybridization experiments were carried out at the China General Microbiological Culture Collection Center (CGMCC) to evaluate the DNA-DNA relatedness between strain $\mathrm{BLN}^{\mathrm{T}}$ and its most closely related neighbour ( $F$. anhuiense CGMCC $1.6859^{\mathrm{T}}$ ) using the optical renaturation rate method (Gillis et al., 1970) and a Perkin Elmer Lambda 35 UV/VIS spectrophotometer. The DNA-DNA relatedness between strain $\mathrm{BLN}^{\mathrm{T}}$ and F. anhuiense CGMCC $1.6859^{\mathrm{T}}$ was $25.7 \%$, a value clearly below the $70 \%$ threshold value generally accepted for species delineation (Stackebrandt et al., 2002).

In view of the combined morphological, physiological, and chemotaxonomic data and of the phylogenetic inference presented here, it is evident that strain $\mathrm{BLN} 2{ }^{\mathrm{T}}$ belongs to the genus Flavobacterium. However, differentiating phenotypic characteristics as well as phylogenetic and genomic distinctiveness distinguish it from recognized species of the genus Flavobacterium. Hence, strain $\mathrm{BLN}^{\mathrm{T}}{ }^{\mathrm{T}}$ is considered 
to represent a novel species in the genus Flavobacterium, for which the name Flavobacterium phragmitis is proposed.

\section{Description of Flavobacterium phragmitis sp. nov.}

Flavobacterium phragmitis [phrag.mi'tis. L. n. phragmites -is a kind of reed growing in hedges and also a scientific generic name (Phragmites); L. gen. n. phragmitis of a reed, of Phragmites australis, the wetland plant from which the type strain was isolated].

Cells are Gram-staining-negative rods approximately 1.0$3.5 \mu \mathrm{m}$ in length and $0.3-0.6 \mu \mathrm{m}$ in diameter, strictly aerobic, non-spore-forming and devoid of flagella, but motile by gliding. Cells are oxidase-negative and catalasepositive. Colonies are yellow, translucent, circular with regular edges and convex. Growth occurs on LB, TSA and NA. Growth occurs at $15-35{ }^{\circ} \mathrm{C}$ (optimum, $30{ }^{\circ} \mathrm{C}$ ), in the presence of $0-3 \%(\mathrm{w} / \mathrm{v}) \mathrm{NaCl}$ (optimum, $1 \%$ ) and at pH 5.5-9 (optimum, pH 7.0). Flexirubin-type pigments are produced, but Congo red is not adsorbed by colonies. Nitrate is not reduced to nitrite. Urease activity is not detected, but arginine dihydrolase activity is present. Starch, Tween 20, Tween 80, aesculin and gelatin are hydrolysed, CM-cellulose is weakly hydrolysed, but agar and L-tyrosine are not hydrolysed. Sodium citrate is not utilized. Indole and $\mathrm{H}_{2} \mathrm{~S}$ are not produced and the methyl red and VogesProskauer reactions are negative. The following carbon sources are utilized in the GN2 MicroPlate: $\alpha$-cyclodextrin, dextrin, glycogen, Tween 40 , Tween $80, N$-acetyl-D-galactosamine, $N$-acetyl-D-glucosamine, L-arabinose, D-fructose, L-fucose, D-galactose, gentiobiose, $\alpha$-D-glucose, lactulose, melibiose, methyl $\beta$-D-glucoside, raffinose, L-rhamnose, sucrose, acetic acid, D-galacturonic acid, D-glucuronide, $\alpha$-butanoic acid, $\alpha$-oxopentanoic acid, DL-lactic acid, propionic acid, L-alaninamide, L-alanine, L-alanyl glycine, L-asparagine, L-aspartic acid, L-glutamic acid, hydroxy-Lproline, L-proline, L-ornithine, L-serine, L-threonine and thymidine. The other substrates in the GN2 MicroPlate are not utilized. Susceptible to $\left(\mu \mathrm{g} \mathrm{ml}^{-1}\right)$ rifampicin (5) and chloramphenicol (50), but resistant to $\left(\mu \mathrm{g} \mathrm{ml}^{-1}\right)$ kanamycin (100), carbenicillin (100), streptomycin (100), hygromycin (50), gentamicin (100) and ampicillin (100). The major respiratory quinone is menaquinone- 6 . The predominant fatty acids ( $>6 \%$ of the total) are iso- $\mathrm{C}_{15: 0}$, summed feature 3 (comprising $\mathrm{C}_{16: 1} \omega 7 c$ and/or $\mathrm{C}_{16: 1} \omega 6 c$ ), $\mathrm{C}_{16: 0} 3-\mathrm{OH}$, $\mathrm{C}_{16: 0}$, iso- $\mathrm{C}_{17: 0} 3-\mathrm{OH}$ and iso- $\mathrm{C}_{15: 0} 3-\mathrm{OH}$.

The type strain, BLN2 $2^{\mathrm{T}}\left(=\right.$ DSM $23314^{\mathrm{T}}=$ CGMCC $\left.1.10370^{\mathrm{T}}\right)$, was isolated from within the roots of reeds (Phragmites australis) collected from the constructed Beijing Cuihu Wetland Park, China. The DNA G $+\mathrm{C}$ content of the type strain is $34.8 \mathrm{~mol} \%$.

\section{Acknowledgements}

We would like to thank Hong Can Liu at CGMCC for his assistance with DNA-DNA relatedness and fatty acid experiments. The type strains of $F$. anhuiense, F. defluvii, F. denitrificans and F. johnsoniae were provided by the CGMCC, DSMZ and JCM, respectively. This work was funded by the Scientific Research Program of Beijing Municipal Commission of Education.

\section{References}

Ali, Z., Cousin, S., Frühling, A., Brambilla, E., Schumann, P., Yang, Y. \& Stackebrandt, E. (2009). Flavobacterium rivuli sp. nov., Flavobacterium subsaxonicum sp. nov., Flavobacterium swingsii sp. nov. and Flavobacterium reichenbachii sp. nov., isolated from a hard water rivulet. Int J Syst Evol Microbiol 59, 2610-2617.

Bernardet, J. F., Segers, P., Vancanneyt, M., Berthe, F., Kersters, K. \& Vandamme, P. (1996). Cutting a Gordian knot: Emended classification and description of the genus Flavobacterium, emended description of the family Flavobacteriaceae, and proposal of Flavobacterium hydatis nom. nov. (basonym, Cytophaga aquatilis Strohl and Tait 1978). Int J Syst Bacteriol 46, 128-148.

Bernardet, J. F., Nakagawa, Y., Holmes, B. \& Subcommittee on the taxonomy of Flavobacterium and Cytophaga-like bacteria of the International Committee on Systematics of Prokaryotes (2002). Proposed minimal standards for describing new taxa of the family Flavobacteriaceae and emended description of the family. Int J Syst Evol Microbiol 52, 1049-1070.

Chun, J., Lee, J. H., Jung, Y., Kim, M., Kim, S., Kim, B. K. \& Lim, Y. W. (2007). EzTaxon: a web-based tool for the identification of prokaryotes based on $16 \mathrm{~S}$ ribosomal RNA gene sequences. Int J Syst Evol Microbiol 57, 2259-2261.

Cowan, S. T. \& Steel, K. J. (1965). Manual for the Identification of Medical Bacteria. New York: Cambridge University Press.

Dong, X.-Z. \& Cai, M.-Y. (editors) (2001). Determination of biochemical properties. In Manual for the Systematic Identification of General Bacteria, pp. 370-398. Beijing: Science Press (in Chinese).

Gillis, M., De Ley, J. \& De Cleene, M. (1970). The determination of molecular weight of bacterial genome DNA from renaturation rates. Eur J Biochem 12, 143-153.

Horn, M. A., Ihssen, J., Matthies, C., Schramm, A., Acker, G. \& Drake, H. L. (2005). Dechloromonas denitrificans sp. nov., Flavobacterium denitrificans sp. nov., Paenibacillus anaericanus sp. nov. and Paenibacillus terrae strain $\mathrm{MH} 72, \mathrm{~N}_{2} \mathrm{O}$-producing bacteria isolated from the gut of the earthworm Aporrectodea caliginosa. Int J Syst Evol Microbiol 55, 1255-1265.

Hucker, G. J. \& Conn, H. J. (1923). Method of Gram staining. N Y State Agric Exp Stn Tech Bull 93, 3-37.

Kim, J. H., Kim, K. Y. \& Cha, C. J. (2009). Flavobacterium chungangense sp. nov., isolated from a freshwater lake. Int J Syst Evol Microbiol 59, 1754-1758.

Komagata, K. \& Suzuki, K. (1987). Lipid and cell-wall analysis in bacterial systematics. Methods Microbiol 19, 161-207.

Lane, D. J. (1991). 16S/23S rRNA sequencing. In Nucleic Acid Techniques in Bacterial Systematics, pp. 115-175. Edited by E. Stackebrandt \& M. Goodfellow. Chichester: Wiley.

Lányí, B. (1987). Classical and rapid identification methods for medically important bacteria. Methods Microbiol 19, 1-67.

Lee, S. H., Kim, J. M., Lee, J. R., Park, W. \& Jeon, C. O. (2010). Flavobacterium fluvii sp. nov., isolated from stream sediment. Int $J$ Syst Evol Microbiol 60, 353-357.

Lewin, R. A. \& Lounsbery, D. M. (1969). Isolation, cultivation and characterization of flexibacteria. J Gen Microbiol 58, 145-170.

Li, Y. H., Zhu, J. N., Zhai, Z. H. \& Zhang, Q. (2010). Endophytic bacterial diversity in roots of Phragmites australis in constructed Beijing Cuihu Wetland (China). FEMS Microbiol Lett 309, 84-93. 
Liu, H., Liu, R., Yang, S. Y., Gao, W. K., Zhang, C. X., Zhang, K. Y. \& Lai, R. (2008). Flavobacterium anhuiense sp. nov., isolated from field soil. Int $J$ Syst Evol Microbiol 58, 756-760.

Liu, Y., Jin, J. H., Zhou, Y. G., Liu, H. C. \& Liu, Z. P. (2010). Flavobacterium caeni sp. nov., isolated from a sequencing batch reactor for the treatment of malachite green effluents. Int J Syst Evol Microbiol 60, 417-421.

Marmur, J. (1961). A procedure for the isolation of deoxyribonucleic acid from microorganisms. J Mol Biol 3, 208-218.

Marmur, J. \& Doty, P. (1962). Determination of the base composition of deoxyribonucleic acid from its thermal denaturation temperature. J Mol Biol 5, 109-118.

Miyashita, M., Fujimura, S., Nakagawa, Y., Nishizawa, M., Tomizuka, N., Nakagawa, T. \& Nakagawa, J. (2010). Flavobacterium algicola sp. nov., isolated from marine algae. Int J Syst Evol Microbiol 60, 344-348.

Park, M., Lu, S., Ryu, S. H., Chung, B. S., Park, W., Kim, C. J. \& Jeon, C. O. (2006). Flavobacterium croceum sp. nov., isolated from activated sludge. Int J Syst Evol Microbiol 56, 24432447.

Park, M., Ryu, S. H., Vu, T. H. T., Ro, H. S., Yun, P. Y. \& Jeon, C. O. (2007). Flavobacterium defluvii sp. nov., isolated from activated sludge. Int J Syst Evol Microbiol 57, 233-237.

Qu, J. H., Yuan, H. L., Li, H. F. \& Deng, C. P. (2009). Flavobacterium cauense sp. nov., isolated from sediment of a eutrophic lake. Int J Syst Evol Microbiol 59, 2666-2669.
Saitou, N. \& Nei, M. (1987). The neighbor-joining method: a new method for reconstructing phylogenetic trees. Mol Biol Evol 4, 406-425.

Sasser, M. (1990). Identification of bacteria by gas chromatography of cellular fatty acids. USFCC Newsl 20, 16.

Smibert, R. M. \& Krieg, N. R. (1994). Phenotypic characterization. In Methods for General and Molecular Bacteriology, pp. 607-654. Edited by P. Gerhardt, R. G. E. Murray, W. A. Wood \& N. R. Krieg. Washington, DC: American Society for Microbiology.

Stackebrandt, E., Frederiksen, W., Garrity, G. M., Grimont, P. A. D., Kämpfer, P., Maiden, M. C. J., Nesme, X., Rosselló-Mora, R., Swings, J. $\&$ other authors (2002). Report of the ad hoc committee for the reevaluation of the species definition in bacteriology. Int J Syst Evol Microbiol 52, 1043-1047.

Tamura, K., Dudley, J., Nei, M. \& Kumar, S. (2007). MEGA4: Molecular evolutionary genetics analysis (MEGA) software version 4.0. Mol Biol Evol 24, 1596-1599.

Wang, Z. W., Liu, Y. H., Dai, X., Wang, B. J., Jiang, C. Y. \& Liu, S. J. (2006). Flavobacterium saliperosum sp. nov., isolated from freshwater lake sediment. Int J Syst Evol Microbiol 56, 439-442.

Xin, Y. H., Liang, Z. H., Zhang, D. C., Liu, H. C., Zhang, J. L., Yu, Y., Xu, M. S., Zhou, P. J. \& Zhou, Y. G. (2009). Flavobacterium tiangeerense sp. nov., a cold-living bacterium isolated from a glacier. Int J Syst Evol Microbiol 59, 2773-2777.

Zhou, Y., Wang, X., Liu, H., Zhang, K. Y., Zhang, Y. Q., Lai, R. \& Li, W. J. (2007). Pontibacter akesuensis sp. nov., isolated from a desert soil in China. Int J Syst Evol Microbiol 57, 321-325. 